\title{
RELATIONSHIP BETWEEN INFLATION AND ECONOMIC GROWTH
}

\author{
DR. TAMMA KOTI REDDY ${ }^{1} \&$ DR IRS SARMA ${ }^{2}$ \\ ${ }^{1}$ Professor \& Head, Department of Economics, IBS Hyderabad IFHE (A constituent of ICFAI Foundation for Higher \\ Education), A Deemed to-be University u/s 3 of The UGC Act 1956, India
}

${ }^{2}$ Associate Professor in Economics, IBS Hyderabad, IFHE (A constituent of ICFAI Foundation for Higher Education), A Deemed to-be University $u$ /s 3 of The UGC Act 1956, India

\section{ABSTRACT}

This paper examines the relationship between Wholesale Price Index Inflation (WPI) and GDP growth in India for the period 1990-91 to 2018-19 using Multiple Regression Analysis. Policy makers and academicians would prefer WPI Inflation than Consumer price Index-Industrial workers (CPI-IW) and GDP Deflator because of its wide coverage and data availability. The study indicates a negative effect of inflation on GDP growth; while both Broad Money (M3) and Gross Domestic Capital formation has a positive effect on GDP growth. The results of the study also indicates a negative effect of GDP on inflation where as Broad Money has a positive effect on Inflation. The authors opine that policy makers should focus on raising output and infrastructure development to achieve a better macroeconomic environment in which growth and social justice can be ensured. The authors stressed the need for attracting private investments in order to enhance the investment level in the economy as it directly contributes for higher economic growth.

KEYWORDS: Inflation, Broad Money, Gross Domestic Capital Formation \& Multiple Regression Analysis

Received: Apr 14, 2020; Accepted: May 04, 2020; Published: Jul 11, 2020; Paper Id.: IJMPERDJUN2020287

\section{INTRODUCTION}

India has been experiencing the problem of continuous raise in prices since 1956-57. The general economic conditions in an economy can be assessed by fluctuations in the prices over a period of time. Persistent increase in the general level of prices can be described as Inflation. Demand-pull factors like High level of Investments, Raise in Money Supply, Raise in Government expenditure, Deficit financing, Black money; cost-push factors like raise in International oil prices, fluctuations in output \& supply, Increase in tax rates and Administered Prices; Other factors like Devaluation, lack of proper implementation of Public Distribution system, Lack of proper formulation and implementation of rational price policies, black marketing and hording of essential commodities etc are the factors responsible for inflationary pressures in any economy. Though Wholesale Price Index is the most widely used price index, GDP at deflator or Consumer Price Index can also be used to measure the variations in the price level in India.

Inflation is inversely associated with economic growth as it affects the interest rate, aggregate demand, exchange rate and international trade. Higher inflation will affect the competitiveness of business firms in the global market, Investments, future profitability of the projects, standard of living of different sections of the people in the society, production, employment and economic growth. Trends in major macroeconomic indicators indicates the health of the economy. Progress in domestic macroeconomic indicators will play a major role in determining the inflationary situation in the economy. Trends in major macroeconomic indicators like Per capita NNP, Money 
supply, Gross capital formation, Fiscal deficit, Current account deficit and Industrial growth indicates the health of the economy. Gross Capital formation has increased significantly during the planning process and has thus generated inflationary tendencies in the economy. Huge Government expenditure and Gross capital formation are passing into the income stream and create conditions for a raise in general price level. Fiscal deficit and current account deficit are also responsible for inflationary pressures in the economy. Raise inn per capita NNP implies a growing demand for goods and services. Fluctuations in the output of food grains and manufactured products is also responsible for inflationary tendencies in the economy.

Table 1.1: Growth in major Macroeconomic Indicators

\begin{tabular}{|c|c|c|c|c|c|c|c|}
\hline Year & $\begin{array}{c}\text { Per capita } \\
\text { NNP } \\
\text { at } \\
\text { Constant } \\
\text { Price } \\
\end{array}$ & $\begin{array}{l}\text { Narrow } \\
\text { Money }\end{array}$ & $\begin{array}{l}\text { Foodgrain } \\
\text { production }\end{array}$ & $\begin{array}{c}\text { Gross Domestic } \\
\text { Capital Formation } \\
\text { (as \% of GDP at } \\
\text { current Market } \\
\text { price) }\end{array}$ & $\begin{array}{l}\text { Combined } \\
\text { Fiscal } \\
\text { Deficit } \\
\text { (as \% of } \\
\text { GDP) } \\
\end{array}$ & $\begin{array}{l}\text { Current } \\
\text { Account } \\
\text { deficit } \\
\text { (as \% of } \\
\text { GDP) }\end{array}$ & $\begin{array}{c}\text { Index of } \\
\text { Industrial } \\
\text { Productio } \\
\text { n }\end{array}$ \\
\hline $\begin{array}{c}1970- \\
71\end{array}$ & 2.4 & --- & 8.94 & 15.1 & 2.3 & -1.05 & 2.5 \\
\hline $\begin{array}{c}1980- \\
81\end{array}$ & 4.5 & --- & 18.1 & 20.6 & 7.3 & -1.70 & 5.6 \\
\hline $\begin{array}{c}1990- \\
91\end{array}$ & 3.1 & 14.6 & 3.2 & 26.0 & 9.1 & -3.40 & 8.5 \\
\hline $\begin{array}{c}1999- \\
00\end{array}$ & 7.0 & 10.6 & -4.5 & 26.8 & 9.1 & -1.15 & 8.1 \\
\hline $\begin{array}{c}2010- \\
11\end{array}$ & 8.3 & 10.0 & 6.59 & 36.5 & 6.9 & -2.7 & 8.2 \\
\hline $\begin{array}{c}2011- \\
12\end{array}$ & 5.1 & 6.0 & 5.93 & 39.0 & 7.8 & -4.2 & 2.9 \\
\hline $\begin{array}{c}2012- \\
13\end{array}$ & 3.3 & 9.2 & -1.52 & 38.7 & 6.9 & -4.7 & 1.1 \\
\hline $\begin{array}{c}2013- \\
14\end{array}$ & 4.6 & 8.5 & 2.97 & 33.8 & 6.7 & -1.6 & -0.1 \\
\hline $\begin{array}{c}2014- \\
15\end{array}$ & 6.2 & 11.3 & 4.91 & 33.5 & 6.7 & -1.3 & 4.0 \\
\hline $\begin{array}{c}2015- \\
16\end{array}$ & 6.7 & 13.6 & -0.19 & 32.1 & 6.9 & -1.1 & 3.3 \\
\hline $\begin{array}{c}2016- \\
17\end{array}$ & 6.8 & -3.9 & 9.5 & 30.9 & 7.0 & -0.7 & 4.6 \\
\hline $\begin{array}{c}2017- \\
18\end{array}$ & 5.7 & 21.8 & 3.59 & 34.2 & 6.6 & -1.8 & 4.4 \\
\hline $\begin{array}{c}2018- \\
19\end{array}$ & 5.6 & 13.6 & 0.05 & 32.2 & 5.9 & -2.1 & 3.6 \\
\hline
\end{tabular}

Source: Economic Survey 2019-20

Table-1.1 presents the trends in the growth of major economic indicators in India since 1970-71. Inflationary tendencies of Indian economy is closely associated with the progress of Major Macroeconomic indicators. Inflation rate accelerated during 1965-1980 due to raise in the growth of Per capita NNP and money supply. High inflation in India was also characterized by fluctuations in the production of foodgrains has resulted a continuous raise in the prices of foodgrains during 1965-67, 1979-80 and the late years of 2000s. The rate of inflation was quite high during 1980s due to huge growth in both fiscal and current account deficits in the latter half of eighties. Price raise in 1990-91 was mainly due to huge growth in both combined fiscal deficit and current account deficit and raise in international oil prices. In the entire Postreform period the growth in Gross capital formation was recorded at high during 2010-11 to 2012-13. As a result, the average annual inflation was registered at 7 per cent during this period. Inflation has been witnessing moderation since 
2014-15 as the economy was able to maintain most of the economic indicators at comfortable level.

Empirical studies on the relationship between Inflation and Economic Growth reveals that there might be positive or negative or no relation between these two variables. In this context, the authors of the article have made an attempt to understand the relationship between inflation and economic growth in India.

\subsection{Objectives of the Study}

The main objective of this study was to study the relationship between the WPI Inflation and Real GDP growth in India for the period 1990-91 to 2018-19. The specific objectives were:

- To study the trends in both Wholesale Price Index Inflation and Consumer Price Index Inflation

- To understand the Weights, number of items and number of quotations pertaining to WPI measurement

- To study the trends in the growth of Broad Money, Gross Domestic Capital formation and real GDP growth of Indian economy for the period 1990-91 to 2018-19

- To examine the relation among Broad Money, inflation, Gross Domestic Capital formation and real GDP growth rate

\subsection{Literature Review}

Chowdhury and Malik (2001) in their study "Inflation and Economic Growth: Evidence from four South Asian countries" have attempted to examine the relationship between Inflation and Economic Growth for the period 1970-2000 using Cointegration test and Error Correction Model. The study reveals a long run positive relationship between inflation and economic growth. The results also indicates that the sensitivity of growth to change in inflation rates is less than that of inflation to changes in growth rates. Chaturvedi et al (2008) studied the inter relationship between Economic Growth, Saving and Inflation for South-East and South-Asia for the period 1989-2003 using 2 stage least squares. The study reveals a negative association between inflation and economic growth and positive association between inflation and saving rate. The study also indicates a positive effect of saving rate on economic growth. Kasidi et al (2013) have studies the impact of inflation on economic growth in Tanzania and found a negative effect of inflation on economic growth.

Chughtai et al, (2015) made an attempt to examine the impact of macroeconomic variable like inflation, interest rate and exchange rate on economic growth for the period 1981-203 using multiple linear regression. The study indicates a negative effect of inflation and interest rate with economic growth, while exchange rate had positive significant effect on the economic growth. Samuel and Nurina (2015) found a negative impact of inflation on economic growth. The study also reveals a positive effect of exchange rate on economic growth and a negative effect of inflation and interest rates on economic growth. Salian and Gopakumar (2010) have analyzed the inflation-growth nexus in India using co integration test and Error Correction Model.The results of their study indicates a long-run negative relationship between inflation and GDP growth rate in India. Aminu Umaru et al (2012) have attempted to examine the impact of inflation on economic growth and development in Nigeria and found that GDP causes inflation and not inflation causing GDP.

Foluso A et al (2017) have studies the existing literature on inflation and economic growth relates to both developed and developing economies. The results indicates a strong evidence in terms of negative relationship between inflation and economic growth. Thanabalasingam 
Vinayagathasan (2013) has employed a dynamic panel threshold growth regression and noted a nonlinear relationship between inflation and economic growth for 32 Asian countries for the period 1980-2009. Kamiar Mohaddes and Mehdi Raissi (2014) have attempted to investigate the long-run relationship between consumer price index industrial workers (CPI-IW) inflation and GDP growth in India for the period 1989-2013 using cross-sectionally augmented distributed lag and the standard panel ARDL method. The results indicates a negative long-run relationship between inflation and economic growth. Gokal and Hanif (2004) in their paper found a weak negative correction between inflation and economic growth.

\subsection{Data \& Methodology}

To analyse above stated objectives, we have employed four major macroeconomic variables i.e. GDP Growth, Money Supply (M3), Inflation (WPI) and Gross Domestic Capital Formation (GDCF). The period of study is taken on an annual basis from the year 1991 to year 2019 sourcing from RBI data and various Economic Surveys.

In this paper we have used Multiple Regression Model (MRM) to assess the relationship among above said variables GDP growth, Money Supply (M3), Inflation, Gross Domestic Capital Formation. We have constructed two Multiple Regression equations in the following manner:

$$
\begin{aligned}
& \boldsymbol{G D P G}=\beta_{0}+\beta_{1} \cdot \mathbf{M 3}+\beta_{2 \cdot} \mathbf{G D C F}+\beta_{3 .} \text { Inflation } \ldots \ldots \ldots . . \\
& \text { Inflation }=\beta_{4}+\beta_{5 .} M 3+\beta_{6 \cdot} \text { GDP Growth } \ldots \ldots \ldots
\end{aligned}
$$

Here,

- $\mathrm{GDPG}=\mathrm{GDP}$ growth rate,

- $\quad$ M3 = Broad Money (Money Supply),

- $\mathrm{GDCF}=$ Gross Domestic Capital Formation,

- $\quad$ Inflation $=$ Consumer Price Index Inflation

- $\beta_{0}, \beta_{4}$ are the intercepts

- $\quad \beta_{1,} \beta_{2}, \beta_{3} \beta_{4} \beta_{5}$ are the coefficients.

In the above equation-1, we have tested the impact of M3, GDCF and Inflation on GDP growth. At the same time we also tested the impact of M3 and GDP growth on Inflation in equation-2

\section{TRENDS OF INFLATION IN INDIA}

Wholesale Price Index (WPI) Inflation is regarded as the inflation of the economy and it can be used for macro-level policy making. Policy makers and academicians would prefer WPI Inflation than Consumer price Index-Industrial workers (CPIIW) and GDP Deflator because of its wide coverage and data availability. Before independence, the first index number of wholesale prices with 1939 as the base year was first released by the Office of the Economic Advisor to the Government of India (Ministry of Industry). After independence the series of index number of WPI in India with 1952-53 as base year was released by the Office of the Economic Adviser in Ministry of commerce \& Industry, GOI. The base year of WPI since then has been revised to 1961-62,1970-71,1981-82,1993-94,2004-05 and 2011-12.

WPI (Base year=1961-62) which stood at 89 in 1950-51 has declined to 74 in 1955-56. The average annual 
inflation during 1950s remained at 1.7 per cent. Price situation has become very difficult during the third five-year plan due to rise in defense expenditure, Raise in International oil prices and shortage of foodgrain production. Price level registered a drop during the Annual plans (1966-69) and the average annual rate of inflation during 1960's remained at 6.4 per cent. The raise in price level during the fourth (1969-74) and fifth five-year plan (974-79) was higher than that of first three fiveyear plans. Fall in agricultural production in 1979-80 and raise in oil prices in 1980 pushed the price level. Annual rate of increase in prices was about 7 to 8 per cent during the sixth five-year plan (1980-85) while it was 7 per cent during seventh five-year plan (1985-90). Price raise rapidly during the Annual Plans (1990-91 to 1991-92) mainly due to rise in international oil prices, raise in the price of foddgrains and raise in administered prices etc. During 1990s average annual rate of inflation stood at 9.5 per cent. Inflation rate was registered in the range of 3-5 per cent during 2000-2008 then it started moving upward before moderating since mid 2014..WPI inflation remained in negative during 2015-16 and increased to 1.7 per cent in 2016-17 and 2.9 per cent in 2017-18 and finally to 4.3 per cent during 2018-19.

Table 2.1: Weights, Items and Number of Quotations in WPI Measurement

\begin{tabular}{|c|c|c|c|c|c|c|c|c|c|}
\hline \multirow[t]{2}{*}{ Group } & \multicolumn{3}{|c|}{ Weight } & \multicolumn{3}{|c|}{ Number of items } & \multicolumn{3}{|c|}{ No. of Quotations } \\
\hline & 1993-94 & 2004-05 & 2011-12 & $\begin{array}{c}1993- \\
94\end{array}$ & $\begin{array}{c}2004- \\
05\end{array}$ & $\begin{array}{c}2011- \\
12\end{array}$ & $\begin{array}{c}1993- \\
94\end{array}$ & $\begin{array}{c}2004 \\
05\end{array}$ & $\begin{array}{c}2011 \\
12\end{array}$ \\
\hline $\begin{array}{l}\text { Primary } \\
\text { Articles }\end{array}$ & 22.02 & 20.12 & 22.62 & 96 & 102 & 117 & 455 & 579 & 983 \\
\hline $\begin{array}{l}\text { Fuel\& } \\
\text { Power }\end{array}$ & 14.23 & 14.91 & 13.15 & 19 & 19 & 16 & 72 & 72 & 442 \\
\hline $\begin{array}{l}\text { Manufactured } \\
\text { Products }\end{array}$ & 63.75 & 64.97 & 64.23 & 318 & 555 & 564 & 1391 & 4831 & 6906 \\
\hline $\begin{array}{l}\text { All } \\
\text { Commodities }\end{array}$ & 100.00 & 100.00 & 100.00 & 435 & 676 & 697 & 1918 & 5482 & 8331 \\
\hline
\end{tabular}

Source: Handbook of Statistics on Indian Economy

Table-2.1 presents Weight, number of items and number of quotations pertaining to WPI measurement. Number of items has been divided into three broad categories i.e, Primary articles, Fuel \& Power and Manufactured products. Changes in weights and items of groups changes as a result of change in structure of the economy over a period of time. It is clear from the table that the weight of primary articles has declined from 22.02 percent in 1993-94 to 20.12 per cent in 2004-05 and then increased to 22.62 per cent in 2011-12. The weight of Fuel\& Power has increased from 14.23 per cent in 1993-94 to 14.91 per cent in 2004-05 and then declined to 13.15 per cent. The weight of manufactured products gradually raised from 63.75 per cent in 1993-94 to 64.97 per cent in 2004-05 and then declined to 64.23 per cent in 2011-12.

The total number of items has been increased significantly from 435 in 1993-94 to 676 in 2004-05 and then to 697 in 2011-12. The number of items under primary articles gradually increased from 96 in 1993-94 to 102 in 2004-05 and then finally to 117 in 2011-12 new series of WPI. The number of items under Fuel \& Power category remains the same in 199394 and 2004-05 series of WPI but declined to 16 in 2011-12 new series of WPI. The number of items under Manufactured category has increased from 318 in 1993-94 to 555in 2004-05 and then to 564 in 2011-12 new series of WPI. Wholesale Price Index Inflation can be considered as more representative with increase in number of quotations from 1918 in 1993-94 to 5482 in 2004-05 and then finally to 8331 in 2011-12 new series.

Table 2.2: Consumer Price Index trends in Emerging and Developing Asia (\%)

\begin{tabular}{|l|c|c|c|c|c|c|c|c|}
\hline \multicolumn{1}{|c|}{ Country } & $\mathbf{2 0 1 4}$ & $\mathbf{2 0 1 5}$ & $\mathbf{2 0 1 6}$ & $\mathbf{2 0 1 7}$ & $\mathbf{2 0 1 8}$ & $\mathbf{2 0 1 9}$ & $\mathbf{2 0 2 0}$ & $\mathbf{2 0 2 1}$ \\
\hline China & 1.98 & 1.44 & 2.003 & 1.558 & 2.10 & 2.9 & 3.04 & 2.5 \\
\hline India & 5.8 & 4.9 & 4.5 & 3.6 & 3.4 & 4.5 & 3.3 & 3.6 \\
\hline Srilanka & 2.763 & 2.23 & 3.98 & 6.58 & 4.27 & 4.30 & 4.66 & 4.65 \\
\hline
\end{tabular}




\begin{tabular}{|l|c|c|c|c|c|c|c|c|}
\hline Philippines & 3.59 & 0.67 & 1.254 & 2.853 & 5.21 & 2.48 & 1.72 & 2.88 \\
\hline Indonesia & 6.39 & 6.36 & 3.52 & 3.80 & 3.29 & 2.82 & 2.87 & 2.93 \\
\hline Malaysia & 3.14 & 2.10 & 2.07 & 3,79 & 0.96 & 0.66 & 0.10 & 2.79 \\
\hline Thailand & 1.89 & -0.90 & 0.18 & 0.66 & 1.06 & 0.70 & -1.06 & 0.56 \\
\hline Vietnam & 4.08 & 0.63 & 2.66 & 3.52 & 3.54 & 2.79 & 3.2 & 3.9 \\
\hline Bangladesh & 7.0 & 6.16 & 5.67 & 5.61 & 5.62 & 5.69 & 5.53 & 5.55 \\
\hline
\end{tabular}

Source: World Economic Outlook Database, April 2020

Table-2.2 presents the trends in Consumer Price Index in Emerging and Developing Asia since 2014.It is noteworthy that none of the countries taken for study in Emerging and Developing Asia have recorded double digit CPI in the last 6 years i.e., from 2014 to 2019 . Average Inflation rate in Thailand till 2019 is less than 1 per cent, but it was much higher for other developing economies in Asia including China and India. As it is clear from the country-wise data contained in Table 1.1. Consumer Price Index is relatively high in India, Srilanka and Bangladesh when compared with the remaining countries in 2019. Inflation rate in most of the emerging and developing Asian economies has been in the range of 3-5 per cent in recent years, which is feasible for achieving economic development. India's inflation rate has recently been in the range of 3-5 per cent.CPI estimated at 4.5 percent in 2019 for India, is projected at 3.3 percent in 2020 and 3.6 percent in 2021. The difference in the inflation rate between the trading partners should be maintained at low in order to have exchange rate stability.

\section{TRENDS IN THE GROWTH OF BROAD MONEY (M3), GDCF, INFLATION AND REAL GDP}

The trends in Growth of Broad Money, GDCF, WPI Inflation rate and Real GDP growth since 1990-91 are presented in the following Graph.

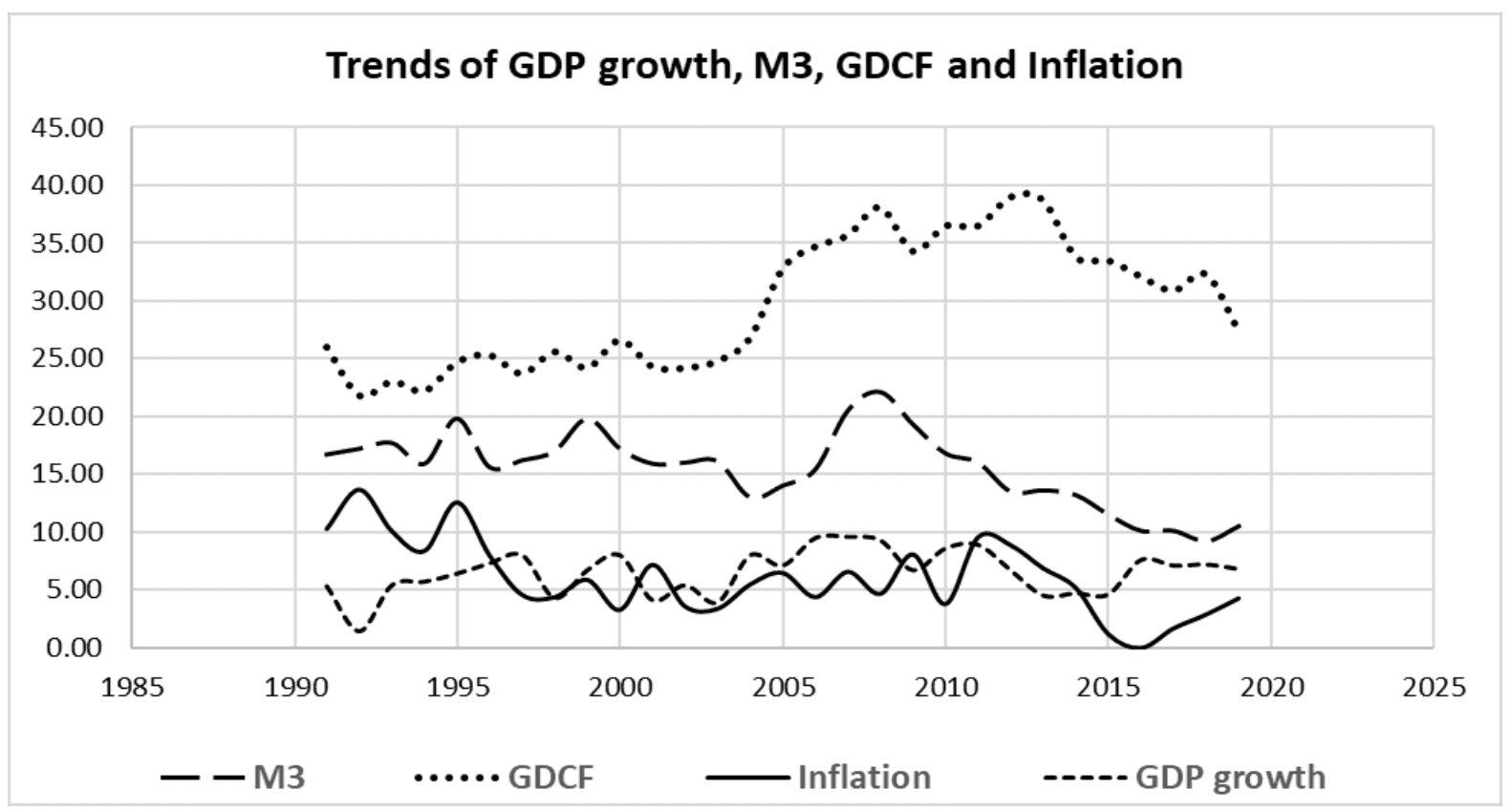

Source: Indian Public Finance Statistics, Handbook of Statistics on Indian economy

The Broad Money (M3) is consisting of currency notes and coins held by the public, demand deposits of all commercial and co-operative banks, other deposits with RBI and Time deposits with the banking system. The proportion of time deposits in broad money has been increasing significantly since 1980-81. The broad money has increased from Rs. 10,960 crore in $1970-71$ to Rs.55,360 crore in $1980-81$ and then finally to Rs. $2,65,828$ crore in 1990-91. Post-reform period also witnessed tremendous growth in terms of total annual variations of money stock or broad money. It has 
increased from Rs. 3,17,049 crore in 1991-92 to 11,24,174 crore in 1999-2000 and then to Rs. 65,04,116 crore in 201011.it stood at Rs. $1,54,30,874$ crore in 2018-19 as compared to that of Rs. 1,05,50,168crofre in 2014-15. The major component responsible for a very rapid raise in broad money in recent years is growing time deposits with the banking system. The average annual growth of Broad Money has increased from 17.04 per cent during 1992-97 to 17.18 per cent during 1997-2002. The same rate declined to 15.8 per cent during 2002-07 and again rose to 17.54 per cent during 2007-12 and finally declined to 11.7 per cent during 2012-17.

Gross Domestic capital formation (GDCF) refers to level of investments. It includes Gross Fixed Capital formation, Changes in Stocks and valuables. During the period of economic planning, GDCF has risen considerably. GDCF at current price rose from Rs. 1133 crore in 1950-51 to Rs.7,297 crore in 1970-71 and Rs. 27,003 crore in 1980-81 and then finally to Rs. 1,46,018 crore in 1990-91. The post-reform period also witnessed a significant progress in terms of increase in Gross Domestic Capital Formation. GDCF has been increased from Rs.1,51,563 crore in 1991-92 to Rs.5,42,682 crore in 2009-10 and then finally to Rs.52,89,400 crore in 2017-18. As per the $1^{\text {st }}$ Advance estimates, GDCF at current prices stood at Rs.59,31,684 crore. The average annual growth of GDCF has increased from 23.78 percent during 1992-97 to 24.98 per cent in the ninth plan, 30.96 per cent in the tenth five-year plan and then finally to 36.88 per cent in the eleventh five-year plan. The same rate declined to 33.8 per cent during 2012-17.

During the entire reform period the annual average rate of inflation was recorded at high in 1991-92 (13.7 per cent) followed by 12.6 per cent in 1994-95 and 9.6 per cent in 2010-11. The annual average rate of inflation which was 8.0 per cent in 1995-96 gradually declined to 4.6 per cent in 1996-97 and further to 4.4 per cent in 1997-98.The same rate again rose to 5.9 per cent in 1998-99 and then declined to 3.3 per cent in 1999-2000 due to better performance of both agriculture and manufacturing, Unexpected change in general price level has caused for higher inflationary pressure in 2000-01. The annual average rate of inflation registered at 7.2 per cent in 2000-01 and declined to 3.6 per cent in 2001-02 and further to 3.4 per cent in 2002-03. The same rate was registered at 6.6 per cent in 2006-07 and 4.7 per cent in 2007-08 and again rose to 8.1 per cent in 2008-09 and around 9.6 per cent in 2010-11. Since 2010-11 it can be observed a gradual decline in the annual rate of inflation and reached to the level of 1.2 per cent in 2014-15. The economy has registered a negative rate of inflation in 2015-16 and witnessed a marginal increase in the rate of inflation in the subsequent years.

The Real GDP which was 5.3 per cent in 1990-91 declined to 1.4 per cent in 1991-92 and then again rose to the level of 8.0 per cent in 1999-00. In the entire post-reform period GDP at factor cost was recorded at high in 2005-06 (9.5 per cent) followed by 9.6 per cent in 2006-07 and 9.3 per cent in 2007-08. The GDP at factor cost remained steady and in the range of 4.5-4.7 per cent during 2012-13 to 2014-15. The average annual growth of GDP at Factor cost was recorded at 7.15 per cent during the period $2015-16$ to $2018-19$.

\section{RESULTS \& DISCUSSIONS}

Table 4.1: Multiple Linear Regression Results

\begin{tabular}{|l|c|c|c|}
\hline Dependent Variable & Coefficient Value & $\mathbf{t}$-value & $\mathbf{P}>|\mathbf{t}|$ \\
\hline GDP Growth & & & \\
\hline M3 $(\beta 1)$ & 0.2327 & 1.9300 & 0.0660 \\
\hline GDCF $(\beta 2)$ & 0.1461 & 2.4800 & $0.0200^{*}$ \\
\hline Inflation $(\beta 3)$ & -0.1966 & -1.8600 & 0.0750 \\
\hline Constant $(\beta 0)$ & -0.3050 & -0.1200 & 0.9060 \\
\hline
\end{tabular}




\begin{tabular}{|l|c|c|c|}
\hline Inflation & & & \\
\hline GDP Growth $(\beta 5)$ & -0.6168 & -2.1800 & $0.0380^{*}$ \\
\hline Money Supply $(\beta 6)$ & 0.5769 & 3.4300 & $0.0020^{*}$ \\
\hline _Constant $(\beta 4)$ & 1.0317 & 0.3400 & 0.7400 \\
\hline
\end{tabular}

As mentioned in the methodology chapter, the two Multiple Regression Equation results are presented in the Table-4.1. From the above Table-4.1, in equation-1, M3 (Money Supply) and GDCF coefficients i.e. $\beta_{1}, \beta_{2}$ are showing positive impact on GDP growth where as Inflation coefficient $\beta_{3}$ is showing negative impact on GDP growth. The M3 (Money Supply) and Inflation coefficients i.e. $\beta_{1}, \beta_{3}$ are insignificant. The GDCF coefficient $\beta_{2}$ is positive and significant at $5 \%$ level indicating for every unit rise in GDCF would lead to 0.15 times rise in GDP growth.

The $\beta_{l}$ coefficient indicating for every unit rise in M3 lead to 0.23 times rise in GDP growth. At the same time for every unit rise in Inflation causing decreasing GDP Growth by 0.20 , signifying cost-push inflation. In the second equation, both M3 and GDP growth coefficients $\beta_{5}, \beta_{6}$ are significant at $1 \%$ and $5 \%$ levels respectively. The M3 coefficient $\beta_{5}$ is showing positive impact, whereas GDP growth coefficient $\beta_{6}$ is showing negative impact on Inflation.

It is evident from the two equations employed in the study that higher economic growth leads to a low price level, whereas higher prices will adversely impact economic growth. It can be observed that Money Supply (M3) coefficient has a positive effect on the GDP growth and Inflation. High growth in money supply and low GDP growth have contributed for raise in price level in the economy. Higher Gross Domestic Capital formation, i.e, increasing the stock of real capital which obviously helps in raising the level of production of goods and services has contributed for higher economic growth

\section{CONCLUSIONS}

From the above discussion it can be concluded that inflation has a negative effect on Inflation on GDP growth; while both Broad Money (M3) and Gross Domestic Capital formation has a positive effect on GDP growth. The results of the study also indicates a negative effect of GDP on inflation, while Broad Money has a positive effect on Inflation. Policy makers should focus on infrastructure development to achieve a better macroeconomic environment in which growth and social justice can be ensured. There is a need for attracting private investments in order to enhance the investment level in the economy as it directly contributes for higher economic growth. Price stability can be achieved by enhancing the output in response to raising the aggregate demand in the economy.

\section{REFERENCES}

1. Aminu Umaru (2012): "Effect of Inflation on the Growth and Development of the Nigerian Economy (An Empirical Analysis", International Journal of Business and Social Science Vol. 3 No. 10 [Special Issue - May 2012

2. Barro, R. J. (1995). Inflation and economic growth. NBER Working Paper 5326. Cambridge,

3. K. V. Nageswara Reddy \& B. Venkata Krishna Reddy, "Global Warming Brings Economical Recession", International Journal of Humanities an d Social Sciences (IJHSS), Vol . 3, Issue 3, pp.9-12

4. F.Kasidi and K. Mwakanemela, (2013) Impact of inflation on economic growth: A case of Tanzania. Asian Journal of Empirical Research, 3(4), 2013, 363-380. [6] M.W.

5. Bishnu Prasad Bhattarai, "Impact Bank Specific and Macroeconomic Variables on Deposit Mobilization of Nepalese Commercial Banks", IMPACT: International Journal of Research in Business Management (IMPACT: IJRBM), Vol. 7, Issue 
7, pp. 39-48

6. Chughtai, M.W. Malik and R. Aftab (2015): "Impact of major economic variables on economic growth of Pakistan", Deta Universitatis Danubius, 11(2), 2015, 94 - 106.

7. Foluso A et al (2017): “Inflation and Economic Growth”, Comparative Economic Research, Volume 20, Number 3, 2017

8. Fischer, S (1993): 'The Role of Macro-economic Factors in Growth', Journal of Monetary Economics, Vol 32(3)

9. Gokal, $\boldsymbol{V}$ and Hanif $\boldsymbol{S}$ (2004): "Relationship between inflation and Economic Growth", Reserve bank of Fiji, Working paper $2004 / 04$

10. Veto Datta \& S. Vasantha, "Positioning of a Brand Through Advertising and Impact of Advertisement on Customers Preference “, BEST: International Journal of Management, Information Technology and Engineering (BEST: IJMITE), Vol. 3, Issue 8, pp. 35-42

11. Kamiar Mohaddes and Mehdi Raissi (2014): “Does Inflation Slow Long-Run Growth in India?” IMF Working paper, $W P / 14 / 222$

12. H.Semuel and S. Nurina, (2015) Analysis of the effect of inflation, interest rates and exchange rates on gross domestic product (GDP) in Indonesia., Proc. International Conf. on Global Business, Economics, Finance and Social Sciences, Bangkok, Thailand, 2015, 1- 13.

13. Anish Buche, "Factors Affecting Volatility in Indian Stock Markets", International Journal of Financial Management (IJFM), Vol. 5, Issue 3,pp.1-8

14. Thanabalasingam Vinayagathasan, (2013): "Inflation and Economic Growth: A Dynamic Panel Threshold Analysis for Asian Economies", GRIPS Discussion Paper G12-17. 

